\title{
The Effect of Auditor Competence, Independence, Task Complexity and Audit Fee on Audit Quality (Survey of Public Accountant Offices in West Jakarta Area)
}

\author{
Achmad Lukman Harun, Jan Hoesada \\ Magister of Accounting, Mercu Buana University \\ J1. Meruya Selatan No.1, West Jakarta, Jakarta 11650, Indonesia
}

\begin{abstract}
This study aims to examine and analyze the effect of Auditor Competence, Independence, Task Complexity and Audit Fees on Audit Quality. This research was conducted in 2019, using primary data collection sourced from the results of data collection in the form of a questionnaire distributed to 11 public accounting firms in the West Jakarta area with a total sample of 89 public accountants. The sample method used is convenience sampling, where respondents are chosen based on availability and ease of getting it and fulfilling specified conditions. Data analysis used multiple regression analysis with the SPSS program. From the results of this study indicate that Auditor Competence affects Audit Quality, Independence and Audit Fees affect Audit Quality while Task Complexity does not affect Audit Quality.
\end{abstract}

Keywords: Auditor Competence, Independence, Task Complexity, Audit Fees and Audit Quality

DOI: $10.7176 /$ RJFA/11-10-13

Publication date:May $31^{\text {st }} 2020$

\section{Introduction}

The increasingly widespread need for public accountant professional services as an independent party, requires the public accounting profession to improve its performance in order to produce reliable audit products for those who need it. In order to improve the attitude of professionalism in carrying out audits of financial statements, public accountants should have adequate audit knowledge and be equipped with an understanding of the professional code of ethics. So that the auditor can maintain the quality of the audit according to Randal et.al in Sirajuddin and Oktaviani (2018) in accordance with general standards that the auditor is required to have sufficient competence in carrying out audit procedures and must maintain an independent mental attitude.

The public acute profession is a very important profession. However, at this time the integrity and objectivity of the public accountants have begun to be doubted by the parties concerned over the public accountant's report due to the rampant financial scandal that occurred lately. Bawono and Singgih in Wiratama and Budiartha (2015) stated that the increasing number of financial scandals that occurred outside and inside the country greatly affected the trust of users of audited financial statements in the public accounting profession.

For example, in the case of alleged bribery of the Ministry of Village officials and BPK Auditors in 2017, the Corruption Eradication Commission (KPK) conducted a arrest operation (OTT) related to bribery cases involving officials of the Ministry of Villages of Disadvantaged Regions and Transmigration (PDTT) and officials and auditors of the Agency of the Republic of Indonesia Financial Examiner. The alleged bribery case handled by the KPK was related to the giving of an unqualified opinion (WTP) by BPK RI to the 2016 PDTT Ministry of Finance's financial statements. The KPK found allegations of corruption in the form of bribes related to giving an unqualified fair opinion (WTP) by BPK RI to the financial statements of The Ministry of PDTT. As for other cases, the case of Ernst \& Young Indonesia's partners who were fined 13 billion rupiah in the United States, Ernst \& Young (EY) public accounting firm partners in Indonesia, namely KAP Purwantono, Suherman \& Surja agreed to pay a fine of US \$ 1 million (around 13.3 billion Rupiah) to the United States regulator, due to being sentenced for failing to audit the financial statements of his clients.

From the above phenomenon it can be concluded from the decline in audit quality that can reduce public confidence in the accounting profession, decrease the credibility of public accountants on the results of audits they do. In this case, the Public Accounting Firm needs to improve the quality of audits to improve the integrity of auditors so that they are back in favor of the interests of the parties concerned with regard to competence, independence, task complexity and cost audits.

\section{Theory Review, Conceptual Frameworksand Hypothesis Development}

2.1 Theory Review

2.1.1 Audit Quality

According to Tandiontong (2016), audit quality as a financial statement-value problem causes material errors and the auditor will find and report those material errors. Arens et.al (2017) states that for public accountants, the trust of clients and users of external financial reports on audit quality is very important. If the user of the audit service 
does not have confidence in the quality of the audit provided by the public accountant or KAP, then the auditor's ability to provide clients and the public will also lose. However, most users of audit services do not have the competence to see audit quality, because of the ability of the audit services. Quality audits are audits that can be followed up by the auditee. This quality must be built from the beginning of the audit to reporting and providing recommendations (Hari et al. 2015).

2.1.2 Auditor Competence

Competence is the knowledge and expertise needed to achieve the tasks that determine individual work (Tunggal, 2016). Mathius in Sirajuddin and Oktaviani (2018) states that competence is related to expertise, knowledge and experience so that competent auditors are auditors who have sufficient knowledge, training, skills and experience in order to successfully complete their audit work. According to Mulyadi (2013), competency indicates the achievement and maintenance of a level of understanding and knowledge that enables a member to provide services with ease and ingenuity.

2.1.3 Independence

According to Arens et.al (2017), independence in auditing means an impartial perspective on the conduct of testing, evaluation of audit results, and preparation of audit reports. The auditor must be independent, meaning that he is not easily influenced, because he is carrying out his work in the public interest. Thus he is not justified in favor of anyone's interests, because however perfect his technical expertise is, he will lose his impartiality which is very important to maintain his freedom of opinion (Agoes, 2017).

2.1.4 Task Complexity

According to Agoes (2017), task complexity is an unstructured, confusing and difficult task. Auditors are always faced with tasks that are many, different, and interrelated with one another. Sanusi and Iskandar in Pratomo (2016) explained that complex tasks have a higher risk of failure, so it is not uncommon for auditors to tend to avoid or withdraw from such tasks, and prefer to involve themselves in tasks that are less complex.

2.1.5 Audit Fee

According to Herawaty in Tarigan and Susanti (2013), fees are a source of income for public accountants and are a problematic dilemma. The auditor gets a fee from the client company being audited. On one hand the auditor must act independently in giving his opinion but on the other hand the auditor also receives compensation for services provided from the client where he is auditing. Independent here means that public accountants prioritize public interests above the interests of management or the interests of the auditors themselves in making audited reports. Therefore, the auditor's partisanship in this matter should be prioritized in the public interest (IAI, 2001).

\subsection{Conceptual Framework}

Based on theory review above, it can be made the following conceptual framework.

Figure 1. Research Conceptual Framework

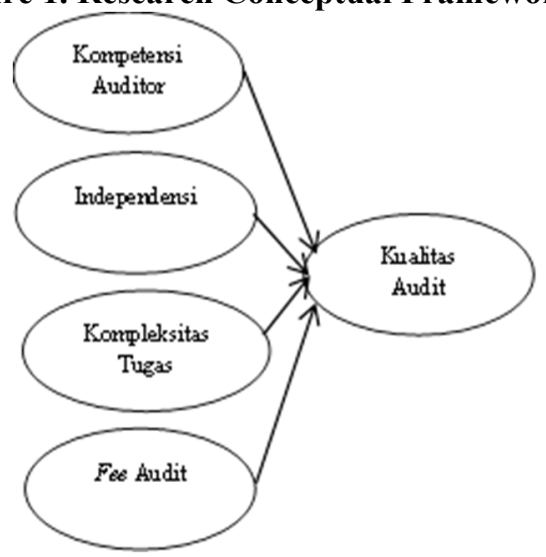

\subsection{Hypothesis Development}

\subsubsection{Effect of Auditor Competence (X1) on Audit Quality (Y)}

Research on auditor competence on audit quality was conducted by Bangun in Tarigan and Susanti (2013) who stated auditor competencies that support audit quality. The competency consists of two dimensions, namely experience and knowledge, and the auditor is the spearhead of the audit task indeed must always improve the knowledge that has been possessed so that the application of knowledge can be maximized in practice.

H1: Auditor competence has an effect on Audit Quality.

2.3.2 Effect of Independence (X2) on Audit Quality (Y)

Rumengan and Rahayu (2014) states that independence influences audit quality. The auditor in giving an opinion on the reasonableness of the financial statements is required to be independent in the interests of all parties 
concerned. The auditor is obliged to be honest with internal and external parties who have confidence in the audited financial statements. Auditor independence is important to maintain, because if the interested parties do not believe in the results of audits from the auditor, the client or third parties will not ask for the services of the auditor again. H2: Independence has an effect on Audit Quality

2.3.3 Effect of Task Complexity (X3) on Audit Quality (Y)

Pratomo (2016) states that task complexity influences audit quality. The complexity of the task is the main determinant of the decision making process and strategy. When faced with tasks with a low level of complexity, decision makers tend to use the compensation process, whereas when faced with assignments with a high level of complexity, they tend to use non-compensation processes and focus on selective information.

H3: Task Complexity has an effect on Audit Quality

2.3.4 Effect of Audit Fee (X4) on Audit Quality (Y)

Research conducted by Chrisdinawidanty, et al (2016) states that audit fees affect audit quality. The amount of member fees may vary depending on the assignment, the complexity of the services provided, the level of expertise required to carry out the service, the fee structure of the Public Accounting Firm (KAP) concerned and other professional considerations. KAP members are not allowed to get clients by offering fees that can damage the image of the profession. Quality is a component of professionalism that truly must be maintained by professional public accountants.

H4: Audit Fee has an effect on Audit Quality

\section{Methods}

3.1 Population and Sample

The population of this research is the registered public accountant and works at the Public Accountant Office in West Jakarta. In determining the population in this study, the authors take data, addresses and names that have been registered at IAPI (Indonesian Public Accountants Association). The distribution was carried out in July 2019 and was carried out on 11 Public Accountant Offices located in the West Jakarta Region.

\subsection{Data Types and Data Collection}

This study uses primary data in form of a public accountant's perception of auditor competence, independence, task complexity, audit fee and audit quality. This research was conducted by distributing research questionnaires directly to respondents by visiting a Public Accountant Office based in the West Jakarta Region.

\subsection{Data Analysis Technique}

This data analysis method includes a questionnaire analysis consisting of data validity and reliability, followed by testing classic assumptions consisting of tests of data normality, multicollinearity, and heteroscedasticity. In addition, multiple linear analyzes were carried out which included the coefficient of determination test, $\mathrm{f}$ test and $t$ test. The regression equation is formulated as follows:

Information: $\quad \mathrm{Y}=$ Audit Quality

$$
\mathrm{Y}=\alpha-\beta 1 \times 1+\beta 2 \times 2-\beta 3 \times 3+\beta 4 \times 4+e
$$

$\alpha=$ Constant

$\beta=$ Regression Coefficient

$\mathrm{X} 1=$ Auditor Competency

$\mathrm{X} 2$ = Independence

$\mathrm{X} 3$ = Task Complexity

X4 = Audit Fee

$\mathrm{e}=$ Error

\section{Results}

4.1 F Test

Table. 1

Results of F Test

\begin{tabular}{|c|c|c|c|c|c|c|}
\hline \multicolumn{2}{|c|}{ Model } & Sum of Squares & df & Mean Square & F & Sig. \\
\hline \multirow{4}{*}{1} & Regression & 304,208 & 4 & 76,052 & 7,438 & 0,000 \\
& Residual & 858,894 & 84 & 10,225 & & \\
& Total & 1163,101 & 88 & & & \\
\hline
\end{tabular}

ANOVA or F test results show that the probability value of the regression model used in the study is 0,000 or smaller than the level of significance of the study (Sig. $<0.05$ ). This indicates that the regression model used in this study is fit for use in hypothesis testing or it can be said that auditor competence, independence, task complexity and audit fees jointly affect audit quality. 


\subsection{Determination Coefficient Test $\left(\mathrm{R}^{2}\right)$}

Table. 2

Results of Determination Coefficient Test $\left(\mathbf{R}^{2}\right)$

\begin{tabular}{|c|c|c|c|c|}
\hline Model & $\mathrm{R}$ & R Square & Adjusted R Square & Std. Error of the Estimate \\
\hline 1 &, 511 &, 262 &, 226 & 3,198 \\
\hline
\end{tabular}

From the table above, it is known that the adjusted R2 is 0.226 . This means that $22.6 \%$ of audit quality variables can be explained by the four independent variables namely auditor competence, independence, task complexity, and audit fees. While the remaining $77.4 \%$ audit quality is influenced by other variables in this research model.

\section{$4.3 \mathrm{t}$ Test}

Table. 3

Results of $t$ Test

\begin{tabular}{|c|c|c|c|c|c|}
\hline \multirow{2}{*}{ Model } & \multicolumn{2}{|c|}{ Unstandardized Coefficients } & Standardized Coefficients & \multirow{2}{*}{ Sig. } \\
\cline { 2 - 4 } & B & Std. Error & Beta & & \\
\hline (Constant) & 27,392 & 6,796 & & 4,031 &, 000 \\
KO & & & & & \\
ID &,- 199 &, 096 &,- 195 & $-2,072$ &, 041 \\
KT &, 375 &, 100 &, 464 & 3,754 &, 000 \\
FA &,- 082 &, 185 &,- 055 & -446 &, 657 \\
&, 546 &, 258 &, 199 & 2,115 &, 037 \\
\hline
\end{tabular}

The test results above show that the value of sig. variable competency 0.041 , Independence 0.000 , and audit fees less than $5 \%(<0.05)$, so that it affects the audit quality. While the value of sig. task complexity variable of 0.657 is greater than $5 \%$, so the independent variable has no effect on audit quality.

4.3.1 Effect of Auditor Competence on Audit Quality

Based on the results that have been tested, the auditor competency variable has a significance value of 0.041 or smaller than 0.05 , it shows that the auditor competency variable influences audit quality.

Auditor competence is an auditor with sufficient and explicit knowledge and experience who can audit objectively, carefully and thoroughly. It is understood that an auditor who has adequate knowledge and experience will better understand various issues in greater depth and more easily follow the development of established regulations. the cause is most respondents are junior auditors. The results of this study are consistent with research conducted by Maharany (2016) which shows that auditor competence influences audit quality.

4.3.2 Effect of Independence on Audit Quality

Based on the results that have been tested, the independence variable has a significance value of 0,000 or smaller than 0.05 , it shows that the independence variable affects the audit quality.

Independence is the attitude expected of a public accountant to have no personal interest in carrying out his duties, which is contrary to the principles of integrity and objectivity. Therefore, it is sufficient to reason that to produce quality audits requires an independent attitude from the auditor. Because if the auditor loses his independence, the audit report produced does not match the reality, so it is not used as a basis for decision making. The results of this study are consistent with research conducted by Agusti and Pertiwi (2013) and Halim, et al (2014) which show that independence influences audit quality.

4.3.3 Effect of Task Complexity on Audit Quality

Based on the results that have been tested, the task complexity variable has a significance value of 0.657 or greater than 0.05 , it shows that the task complexity variable has no effect on audit quality.

This condition shows that the complexity of the tasks in the audit work received by the auditor within a certain period is reasonable and the public accounting firm has an obligation to check the fairness of the client's financial statements and issue an opinion on the audited financial statements. This can be caused by auditors who already have high professional attitudes and qualified competence will not feel hampered by the audit process by the complexity of the existing tasks. The results of this study are consistent with Pratomo's (2016) research which shows that task complexity does not affect audit quality.

4.3.4 Effect of Audit Fee on Audit Quality

Based on the results that have been tested, the audit fee variable has a significance value of 0.037 or smaller than 0.05 , it shows that the audit fee variable influences the audit quality.

When the audit fee is higher, the quality of the resulting audit is also higher because the audit procedures to be carried out are also broader, thus the audit results produced can be trusted and accurate. Auditors with high audit fees will conduct a more extensive and in-depth audit procedure on the client's company so that possible irregularities in the client's financial statements can be detected. Detection of discrepancies reflects the high quality of the audit process, this is because the quality of the audit process is the implementation of the audit with the correct application of accounting standards and audit standards by the auditor. The results of this study are 
consistent with research conducted by Chrisdinawidanty (2016) and Sulfati (2016) research which shows that audit fees have an influence on audit quality.

\section{Conclusions and Recommendations}

5.1 Conclusions

1. Auditor competence affects audit quality.

2. Independence influences Audit Quality

3. Task complexity does not affect the audit quality.

4. Audit Fee influences Audit Quality

\subsection{Recommendations}

1. To be able to improve Business Continuity and maintain public accounting firms (KAP) from competition, KAP in the West Jakarta Region should increase their auditor's competence, namely by conducting more training and more often or even always following continuing professional education.

2. To increase auditor independence, it is suggested to be able to improve independence by communicating openly with fellow auditors if they feel there are indications that force the auditor to reduce independence, or it can also notify the supervisor if the auditor feels there is a disturbance in his independence, so that independence is expected auditors stay awake.

3. For audit fees, so that there are rules or standards that regulate how much fees should be received, so as not to ignore the auditing process and no more fee wars between public accounting firms, which makes audit quality poor. With the rules regarding the fee, it is predicted that the audit quality will be better, because with fees that are in accordance with the requirements, the entire audit process will be fully carried out without missing anything.

4. Further research is suggested to be able to conduct research in other cities, so that later the results can be generalized to a broader scope so to strengthen external validity further research is needed and add other variables that can affect audit quality, or examine other independent variables such as compliance pressure , professional skepticism, auditor ethics, audit experience, accountability and others.

\section{References}

Abdul, dkk. (2014). Effect of Competence and Auditor Independence on Audit Quality with Audit Time Budget and Professional Commitment as a Moderation Variable. International Journal of Business and Management Invention, Volume 3, Issue 6.

Agoes, S. (2017). Auditing: Instructions Practical Examination of Accountants by Public Accountants. Jakarta: Salemba Empat.

Agusti and Pertiwi. (2013). Influence Competence, Independence and Professionalism on Audit Quality (Empirical Studies in Public Accountants in Sumatra). Journal of Economics Volume 21, Number 3.

Ardani. (2017). Effect of Tenure Audit, Audit Rotation, Audit Fee on Audit Quality with the Audit Committee as a Moderation Variable (Study of Financial Sector Companies Listed on the Indonesia Stock Exchange in 2010-2014). Journal of Accounting, Vol 6, No. 1.

Arens, et.al. (2017). Auditing \& Assurance Services (Integrated Approach). Jakarta: Erlangga Publisher.

Chrisdinawidaty, et al. (2016). The Effect of Auditor Ethics and Audit Fees on Audit Quality (Case Study at a Public Accountant Office in the Bandung Area). E-proceeding of Management: Vol. 3 No. 3

Ghozali, I. (2013). Multivariate Analysis Application with IBM SPSS 21 Program. Semarang: Diponegoro University Publisher Agency.

Hari et al. (2015). Influence Competence, Independence, Work Experience, Task Complexity Towards Audit Quality of Inspectorate Officers in Regional Financial Oversight and Reward as Moderating Variables. SOROT Journal, Volume 10, Number 1.

Hasbullah, et al. (2014). Influence Audit Expertise, Task Complexity, and Professional Ethics of Audit Quality (Study at the Denpasar City Government Inspectorate and Gianyar Regency Government Inspectorate. EJournal S1 Ganesha University of Education Volume 2 No 1.

Kovinna and Betri. (2014). Influence of Independence, Work Experience, Competence, and Ethics of Auditors on Audit Quality (Case Study at a Public Accountant Office in Palembang City). Accounting journal.

Mulyadi. (2013). Auditing. Jakarta: Salemba Empat

Onaolopo et al. (2017). Effect of Audit Fees on Quality Audit: Evidence from Cement Manufacturing Companies in Nigeria. European Journal of Accounting, Auditing and Finance Research, Vol.5 No.1.

Pandoyo. (2016). The Effect of Auditor Competence, Independence, Audit Experience, Organizational Culture and Leadership Against Auditor Professionalism and Its Implication on Audit Quality. International Journal of Advanced Research, Volume 4 Issue 5.

Pratomo. (2016). Influence of Competence, Task Complexity and Time Budget Pressure on the Quality of Local 
Government Internal Audit. Journal of Accounting and Business Vol 16, No. 2.

Rahayu and Suryono. (2016). Effect of Auditor Independence, Auditor Ethics, and Auditor Experience on Audit Quality. Journal of Science and Accounting Research: Volume 5, Number 4.

Rumengan and Rahayu. (2014). Effect of Competence, Independence and Work Experience on Audit Quality (Survey of KAP Auditors in Bandung). Telkom University Economic Journal.

Sirajuddin and Oktaviani. (2018). Auditor Integrity as Moderating: Influence of Competence, Independence, Task Complexity and Time Budget Audit on Audit Quality (Emprising Study on the Public Accountant Office and the Republic of Indonesia Republic of Indonesia's Financial Audit Agency in Palembang). Balance Vol. XV No. 1

Sulfati. (2016). The Effect of Fee and Tenure Audit on Audit Quality in Public Accounting Firms. National Seminar and The 3rd Call for Syariah Paper.

Tandiontong, M. (2016). Audit Quality and Measurement. Bandung: Alfabeta

Tarigan and Susanti. (2013). The Effect of Competence, Ethics and Audit Fees on Audit Quality. Journal of Accounting, Volume 13, Number 1.

Tjun, et al. (2012). Effect of Auditor Competence and Independence on Audit Quality. Journal of Accounting Vol. 4 No. 1

Single, A.W. (2016). Audit Basics. Jakarta: Harvarindo

Wiratama and Budiartha. (2015). The Influence of Independence, Work Experience, Due Professional Care and Accountability on Audit Quality. E-Journal of Udayana University Accounting 10.1.

Wibowo. (2013). Work management. Jakarta: Rajawali Press 